\title{
COMPARATIVE PARASITISM OF THE FISH PLAGIOSCION SQUAMOSISSIMUS IN NATIVE AND INVADED RIVER BASINS
}

\author{
A. C. F. Lacerda, R. M. Takemoto, M. Tavares-Dias`, R. Poulin†, and G. C. Pavanelli \\ Research Nucleus in Limnology, Ichthyology and Aquaculture, State University of Maringá, 87020-900, Maringá, Paraná, Brazil. e-mail: lacerdaacf@ \\ gmail.com
}

\begin{abstract}
Biological invasions are considered a major threat to biodiversity around the world, but the role of parasites in this process is still little investigated. Here, we compared parasite infections of a host species in the areas where it originated and where it was introduced, and in native and introduced species in the same environment, using the endoparasites of the fish Plagioscion squamosissimus (Sciaenidae) in 3 Brazilian basins. Samples were taken in 2 rivers where the species is native, i.e., Solimões River (SO) and Tocantins River (TO), and where the species was introduced, the upper Paraná River (PR). In addition, abundances of diplostomids and larval nematodes were compared between $P$. squamosissimus and 2 native competitors in the PR, Hoplias malabaricus and Raphiodon vulpinus. In total, 13 species of endoparasites were recorded, but only Austrodiplostomum sp. and cestode cysts were present in all localities. Although infracommunity richness was similar, their species composition was slightly different among localities. General linear models using the relative condition factor of fish as response variables, and abundance of the most prevalent parasites as possible predictors showed that the condition of fish is negatively correlated with parasite abundance only in the native range (TO). Abundance of diplostomid eye flukes was higher in the PR, and in the native species H. malabaricus when compared to the invader, which might present an advantage for P. squamosissimus if they compete for prey. However, although $P$. squamosissimus may have lost some of its native parasites during its introduction to the PR, it is now possibly acting as a host for native generalist parasites.
\end{abstract}

Invasive species are among the major factors responsible for biodiversity loss worldwide (Mack et al., 2000; Rahel, 2002; Simberloff, 2003). Usually, the idea of invasive species is closely linked to the introduction of species from 1 continent to another. However, in the case of the freshwater biota, the translocation of species from a single river basin to another within the same continent represents a threat as well. In Brazil, $87 \%$ of introductions consist of fish species originating from other countries, whereas $13 \%$ are species transferred from other Brazilian basins (Agostinho et al., 2005). This kind of introduction between basins within the same continent, where the introduced species are "translocated," is particularly important in Brazil, which has of a rich river network wherein many of the basins have been isolated from each other for a very long time, allowing the development of distinct communities.

More than 20 species of fish have been translocated in the upper Paraná River, located in the southeast and southern regions of Brazil, some intentionally, with the purpose of increasing fisheries diversity (Agostinho et al., 2007). This was the case for Plagioscion squamosissimus (Sciaenidae), popularly known as curvina, introduced in the Pardo River (São Paulo State), Paraná River basin, in the 1960s (Nomura, 1984 in Carnelós and Benedito-Cecílio, 2002). This fish species is native to the Amazonas River basin, including the Tocantins-Araguaia sub-basin, in northern Brazil, and it is now the most successful introduced species in terms of abundance and biomass in the upper Paraná River floodplain (Agostinho et al., 2007). The endoparasites of $P$. squamosissimus have been studied by a few researchers, focusing on 1 parasite species (Kohn et al., 1995; Souza, 1998; Martins et al., 1999, 2001; Machado et al., 2005; Tavares et al., 2007), but no effort has been made to investigate the parasite community and the differences in parasitism between basins or between native and introduced ranges. The objective of the present study was to compare parasitism in the fish where it originated and where it was introduced, testing the hypothesis that

Received 8 June 2011; revised 24 August 2011, 16 February 2012, 26 March 2012; accepted 2 April 2012

*Embrapa Amapá, 68903-419, Macapá, Amapá, Brazil.

$\dagger$ Department of Zoology, University of Otago, P.O. Box 56, Dunedin 9054, New Zealand.

DOI: $10.1645 / G E-2882.1$ introduced parasites have gone through ecological bottlenecks in the environments where the fish is not native, leading to an attenuation of the parasite load (species richness, abundance, and effect on the host's condition factor) in the invaded environment. To accomplish this goal, we worked on a biogeographic scale, analyzing endoparasites of $P$. squamosissimus in 2 environments where the species is native, Solimões River and Tocantins River, and 1 habitat where the species was introduced, the upper Paraná River.

In addition, in order to compare parasitism in native and introduced species in the same current habitats, we performed a community-scale study in the upper Paraná River, comparing the abundance of diplostomid trematodes and larval nematodes and their influence on host condition in the introduced $P$. squamosissimus and in 2 native fish species with similar feeding habits, Hoplias malabaricus (Erythrinidae) and Raphiodon vulpinus (Cynodontidae) (Luz-Agostinho et al., 2008). The present effort represents the first study on the parasite fauna of an invasive fish considering native and invaded environments in Brazilian waters.

\section{MATERIALS AND METHODS}

Samples were obtained from 3 study areas: (1) the upper Paraná River floodplain, Paraná River basin (PR) (22 46 $\left.11^{\prime \prime} \mathrm{S}, 53^{\circ} 17^{\prime} 6^{\prime \prime} \mathrm{W}\right)$; (2) Coari Lake, middle Solimões River (SO), Amazonas basin $\left(4^{\circ} 2^{\prime} 0^{\prime \prime} \mathrm{S}\right.$, $63^{\circ} 15^{\prime} 16^{\prime \prime} \mathrm{W}$ ); and (3) Lajeado reservoir, Tocantins River (TO), Tocantins-Araguaia sub-basin, part of the Amazonas basin $\left(10^{\circ} 66^{\prime} 55^{\prime \prime} \mathrm{S}\right.$, $\left.48^{\circ} 42^{\prime} 36^{\prime \prime} \mathrm{W}\right)$. Plagioscion squamosissimus is native to the latter 2 basins and is considered an invasive species in the upper Paraná River (Agostinho et al., 2007). Collections were performed in September 2008/ 2009 (PR), October/2008 (SO), and October/2009 (TO). All fish were captured by gill nets set for 24-hr periods; they were then taken to the laboratory and killed by an overdose of MS-222. All fish were measured (standard length) and weighed, and the body condition of each individual was calculated using the relative condition factor proposed by Le Cren (1951), which is the ratio between a fish's observed weight and that predicted by the weight-versus-length regression across all fish in the sample.

Each fish was opened by a ventral incision, and each organ and the body cavity were examined for parasites separately using a stereomicroscope. Helminths were removed from the organs and body cavity, fixed in $5 \%$ formalin, and later transferred to $70 \%$ ethanol. Digeneans, cestodes, and acanthocephalans were stained with acetic carmine, and nematodes were cleared with lactophenol. Permanent slides were prepared using 
TABle I. Endoparasites of Plagioscion squamosissimus collected in the rivers Paraná, Solimões, and Tocantins $(\mathrm{P}=$ prevalence, $\mathrm{MA}=$ mean abundance \pm standard deviation).

\begin{tabular}{|c|c|c|c|c|c|}
\hline Locality & Group & Parasite & Infection site & $P(\%)$ & $\mathrm{MA} \pm \mathrm{SD}$ \\
\hline & Cestoda & Cysts* & Mesentery & 60.0 & - \\
\hline & & Contracaecum sp. 2 (larvae) $\dagger$ & Mesentery & 2.9 & $0.03 \pm 0.18$ \\
\hline & Acanthocephala & Neoechinorhynchus sp. (larvae) & Mesentery & 22.9 & $0.40 \pm 0.69$ \\
\hline \multirow[t]{5}{*}{ Solimões $(\mathrm{n}=35)$} & Digenea & Austrodiplostomum sp. (larvae)* & Aqueous humour & 40.0 & $4.34 \pm 7.79$ \\
\hline & Nematoda & Contracaecum sp. 2 (larvae) $\dagger$ & Mesentery & 57.1 & $2.74 \pm 5.17$ \\
\hline & & Terranova sp. (larvae) & Mesentery & 97.1 & $23.57 \pm 33.54$ \\
\hline & Acanthocephala & Neoechinorhynchus macronucleatus & Intestine & 8.6 & $0.31 \pm 1.16$ \\
\hline & & Radinorhynchus plagioscionis & Intestine & 57.1 & $3.46 \pm 9.16$ \\
\hline \multirow[t]{3}{*}{ Tocantins $(\mathrm{n}=35)$} & Digenea & Austrodiplostomum sp. (larvae)* & Aqueous humour & 8.3 & $0.11 \pm 0.53$ \\
\hline & & Digenea gen. sp. & Intestine & 2.8 & 0.03 \\
\hline & Cestoda & Cysts* & Mesentery & 40.0 & - \\
\hline
\end{tabular}

* Parasites recorded in 3 localities.

$\uparrow$ Parasites recorded in 2 localities.

Canada balsam (see Eiras et al., 2002). Ectoparasites were not considered in this study. Data regarding H. malabaricus and its parasites were derived from a random subset of 35 fish taken from the samples obtained by Almeida (1998), while data for R. vulpinus were obtained from Alvarenga (2008). The sampling methods for fish and parasites used by Almeida (1998) and Alvarenga (2008) were the same as for the present study; they were developed in the same region, by the same research group. Given that the comparative data on native fish were collected years before data from $P$. squamosissimus, we acknowledge that temporal variation may partially affect the present comparison at the community scale.

Biogeographic-scale analyses included $P$. squamosissimus from the 3 localities. A discriminant function analysis (DISCRIM) was performed in order to detect similarities between the environments, using parasite abundances, i.e., number of parasites per individual fish for each parasite species, as independent variables, and removing outliers. To compare the abundance of parasites present in the 3 localities, the Kruskal-Wallis rank sum test was performed, followed by pairwise contrasts between localities. A general linear model (GLM) was constructed using infracommunity richness, i.e., the number of parasite species per individual fish, as a response variable, assuming a Gaussian distribution, and locality of origin and host length as possible predictors. To determine if the condition of hosts was affected by the abundance of parasites, 3 GLMs were performed using the condition of hosts in each locality as response variables and abundance of parasites and interactions between abundances as possible predictors. The condition of hosts in TO was logtransformed to fit a Gaussian distribution. GLMs and DISCRIM included only parasite species with a local prevalence higher than $10 \%$ (Bush et al., 1997). For encysted larval cestodes occurring at very high abundances, cysts were not counted; only the presence or absence of cysts in a fish was recorded.

Community-scale analyses included $P$. squamosissimus in the invaded environment, and 2 fish species native to the PR, i.e., H. malabaricus and $R$. vulpinus. To determine if the abundance of Contracaecum sp. 2 (which infected both the introduced and native fish) affected the condition of native fish more than the condition of the invader, a GLM was performed with the condition of hosts as a response variable, and abundance of Contracaecum spp. and host species as possible predictors (condition data for $H$. malabaricus were not available). In addition, a Kruskal-Wallis test was performed to compare the abundance of Contracaecum spp. among the 3 hosts, and a Mann-Whitney $U$-test was used to compare abundance of diplostomid eye flukes between $P$. squamosissimus and H. malabaricus (they do not occur in $R$. vulpinus, either because of incompatibility or absence of exposure). All GLMs used Akaike's information criterion for the selection of the best models, and all analyses were conducted considering $\alpha=0.05$. The DISCRIM was performed using STATISTICA software, version 7.1 (Statsoft, Tulsa, Oklahoma); GLMs and other tests were conducted in R, version 2.7.2 (R Development Core Team, 2010).

\section{RESULTS}

In each locality, $35 \quad P$. squamosissimus individuals were collected, totaling 105 specimens examined. Considering all the localities, 6,127 endoparasites belonging to 13 species were recorded parasitizing $P$. squamosissimus. Parasite species and infection levels in all localities are presented in Table I. The only parasites observed in all 3 localities were Austrodiplostomum sp. (larvae) and cysts of cestodes. Contracaecum sp. 2 (larvae) occurred in 2 localities, SO and PR.

The discriminant function analysis showed that the 3 localities have perfectly distinguishable communities of parasites $(\Lambda=0.08$, $P<0.0001)$. The lowest and highest scores of the discriminant variables were for the ascaridoid parasites (all larvae) $(-0.760)$ and Austrodiplostomum sp. (larvae) (0.206) in the first discriminant function, and Rhadinorhynchus plagioscionis $(-0.443)$ and Austrodiplostomum sp. (larvae) (0.422) in the second discriminant function (Fig. 1).

The abundance of Austrodiplostomum sp. (larvae) was significantly different among localities $(H=53.8, P<0.0001)$; Paraná presented the highest abundance compared to Solimões ( $U=$ 1003.5, $P<0.0001)$ and Tocantins $(U=1146, P<0.0001)$, and Solimões exhibited a higher abundance than Tocantins $(U=883$, $P<0.0001)$. Although Contracaecum sp. 2 larvae were present in the Paraná and Solimões Rivers, only 1 specimen was found in Paraná. In the GLM performed with infracommunity richness as a response variable, and locality and length as possible predictors, only length emerged as a significant predictor $(t=4.17, P<$ $0.001)$. Thus, even if infracommunity richness was higher in the Solimões River, it was mostly because the fish were of greater lengths in this locality, and the infracommunity richness was positively correlated with length. 


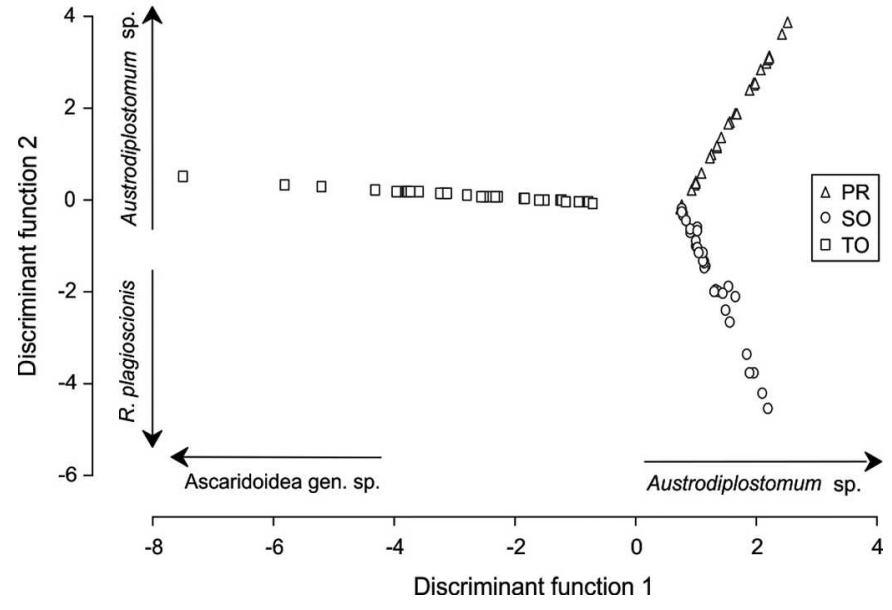

Figure 1. Representation of species of endoparasites of Plagioscion squamosissimus collected in the rivers Paraná (PR), Solimões (SO), and Tocantins (TO), against their values for the 2 discriminant functions.

According to the GLMs performed using host condition as response variables and parasite abundances as possible predictors (Table II), none of the parasites was a significant predictor of the condition factor of hosts in the Paraná River. In the Solimões River, $R$. plagioscionis was the only significant predictor of fish condition, with the abundance of this parasite and host condition being positively correlated; however, this effect disappeared after removal of a single extreme outlier (with $>5$ times more $R$. plagioscionis worms than any other fish). The abundance of ascaridoid larvae was the only predictor selected in the model using condition of fish from Tocantins as a response variable, and it was negatively correlated with the condition of fish. Although different parasite species are involved, the comparison still allows a tentative evaluation of the impact of parasitism on the same fish species, but in different localities.

\section{DISCUSSION}

The negative correlation between the condition of hosts and the abundance of ascaridoids in the Tocantins River reflects the pathogenicity of the nematode larvae belonging to this order, which are known to cause serious damage to their hosts (Moravec, 1998). It is noteworthy that all the parasites of $P$. squamosissimus in the Paraná River were larvae. Perhaps native parasites were not able to reproduce in the new hosts, and the latter only serve as paratenic hosts for the larvae of native generalist parasites. An exception might be Austrodiplostomum sp., which reached high abundance and prevalence levels in $P$. squamosissimus from the Paraná River.

The GLM performed with the condition of the hosts $P$. squamosissimus and R. vulpinus in the Paraná River as response variables showed that the abundance of Contracaecum spp. larvae is not a good predictor of host condition. The only predictor selected in the final model was host species, which revealed that the condition of $R$. vulpinus was significantly lower than that of the invasive fish $(t=-2.44, P<0.02)$, but it was not influenced by the abundance of the parasite. According to the KruskalWallis test comparing Contracaecum spp. larvae abundance among the hosts $P$. squamosissimus, $H$. malabaricus, and $R$. vulpinus in the Paraná River, there were significant differences in parasite abundance among the 3 fish species $(H=11.32, P<$ 0.004). Plagioscion squamosissimus and $R$. vulpinus harbored significantly different numbers of Contracaecum larvae $(U=745$, $P<0.05)$, but the major difference was between the natives $H$. malabaricus and $R$. vulpinus $(U=858, P<0.001)$ (Fig. 2). This may reflect differences in the feeding habits of the 3 species of hosts. According to Almeida (1998), the endoparasite fauna of $H$. malabaricus in the upper Paraná River consists of 9 species of digeneans (including 6 larval forms), 1 tapeworm species, 7 nematode species (including 3 larval forms), and 1 species of acanthocephalan. In contrast, according to Alvarenga (2008), $R$. vulpinus was parasitized only by larval forms of 3 species of nematode and 1 acanthocephalan species. Thus, based on the composition of the endoparasite fauna, it is possible that $P$. squamosissimus and H. malabaricus have more similar diets and, consequently, exposure to infection.

In contrast, abundance of diplostomid eye flukes was slightly higher, but significantly so, in the native fish $H$. malabaricus than in the introduced fish $P$. squamosissimus $(U=424.5, P=0.02760)$ (Fig. 3). This result contrasts with the report of Machado et al. (2005), who studied parasitism by eye flukes in 6 different host species, including $P$. squamosissimus and $H$. malabaricus, in the upper Paraná River. The studies that were performed in the Paraná River basin with P. squamosissimus and Austrodiplostomum sp. showed different values of prevalence and intensity for this parasite, i.e., $100 \%$ prevalence and 2 to 100 parasites per host

TABLE II. Predictors retained in the best models of GLM analyses, using Akaike's information criterion, with condition of fish as response variables (assuming Gaussian distribution) and abundance of parasites as possible predictors ( $\mathrm{PR}=$ Paraná River, $\mathrm{SO}=$ Solimões River, TO $=$ Tocantins River).

\begin{tabular}{|c|c|c|c|c|c|c|}
\hline \multirow[b]{2}{*}{ Predictors } & \multicolumn{6}{|c|}{ Condition of hosts } \\
\hline & $t$ & $P$ & $t$ & $P$ & $t$ & $P$ \\
\hline Cestode cysts & 1.72 & 0.096 & - & - & -1.15 & 0.259 \\
\hline Neoechinorhynchus sp. (larvae) & 1.37 & 0.178 & - & - & - & - \\
\hline Radinorhynchus plagioscionis & - & - & 2.76 & $0.009^{*}$ & - & - \\
\hline Contracaecum sp. 2 (larvae) $\times$ Terranova sp. (larvae) & - & - & -1.52 & 0.139 & - & - \\
\hline Ascaridoidea gen. sp. (larvae) & - & - & - & - & -2.08 & $0.046^{*}$ \\
\hline Cestode cysts $\times$ Ascaridoidea gen. sp. (larvae) & - & - & - & - & 1.45 & 0.157 \\
\hline
\end{tabular}

* Significant values. 


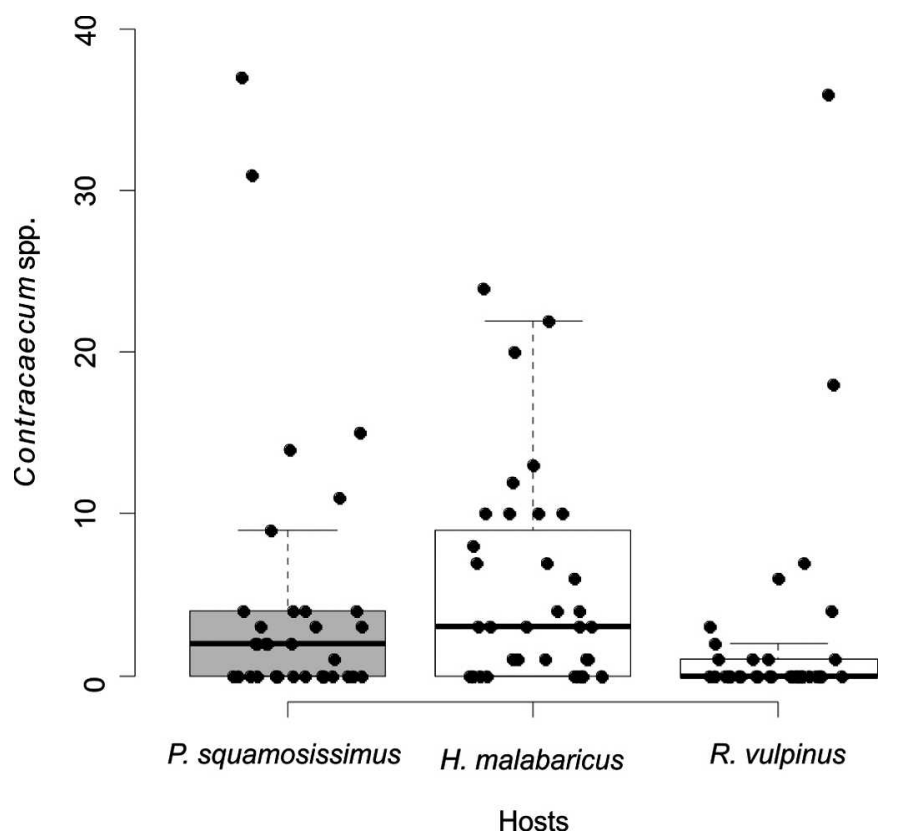

FIgURE 2. Abundance of Contracaecum spp. larvae in the introduced fish Plagioscion squamosissimus, and in the native hosts Hoplias malabaricus and Raphiodon vulpinus in the upper Paraná River (box plots represent medians, interquartile ranges, and minimum-maximum ranges without outliers).

(Kohn et al., 1995), 46\% prevalence and 1 to 34 parasites per host (Martins et al., 1999), 53\% prevalence and 1 to 33 parasites per host, and $95 \%$ prevalence and 1 to 397 parasites per host (Machado et al., 2005). These differences may be due to possible seasonal fluctuations in the parasite component population, as shown for diplostomids parasitizing $P$. squamosissimus in the Volta Grande reservoir (Martins et al., 2001). The low abundance of eye flukes in $P$. squamosissimus compared to other native fish species may benefit the introduced predator if competing for prey, given that $P$. squamosissimus and $H$. malabaricus overlap in diet in the upper Paraná River floodplain (Luz-Agostinho et al., 2008). Lower parasite abundance in introduced fish compared to native competitors has also been reported by Roche et al. (2010) for the invasive Oreochromis niloticus in Mexico.

The taxonomy of larval diplostomids is complicated, involving slight phenotypic variation (Seppälä et al., 2007) and several cryptic species (Locke et al., 2010). The parasite was earlier recorded in the upper Paraná River region as Diplostomum (Austrodiplostomum) spp., with the subgenus later recognized as a genus (Niewiadomska, 2005). The high abundance of Austrodiplostomum sp. in $P$. squamosissimus in the Paraná River basin (Kohn et al., 1995; Souza, 1998; Machado et al., 2005), and the recent record of this eye fluke parasitizing native hosts (Yamada et al., 2008; Zica et al., 2009) have led some authors to suggest that the diplostomid is an invasive species in the upper Paraná River (Machado et al., 2005; Yamada et al., 2008; Takemoto et al., 2009; Zica et al., 2009). However, according to our results, this is unlikely because (1) diplostomids use migratory birds as final hosts, and this could have reduced or eliminated geographic barriers for the parasite, and (2) abundance and prevalence on $P$. squamosissimus are much higher in the Paraná River than in its native range. So, instead of introducing a new parasite into the new habitat, it seems more

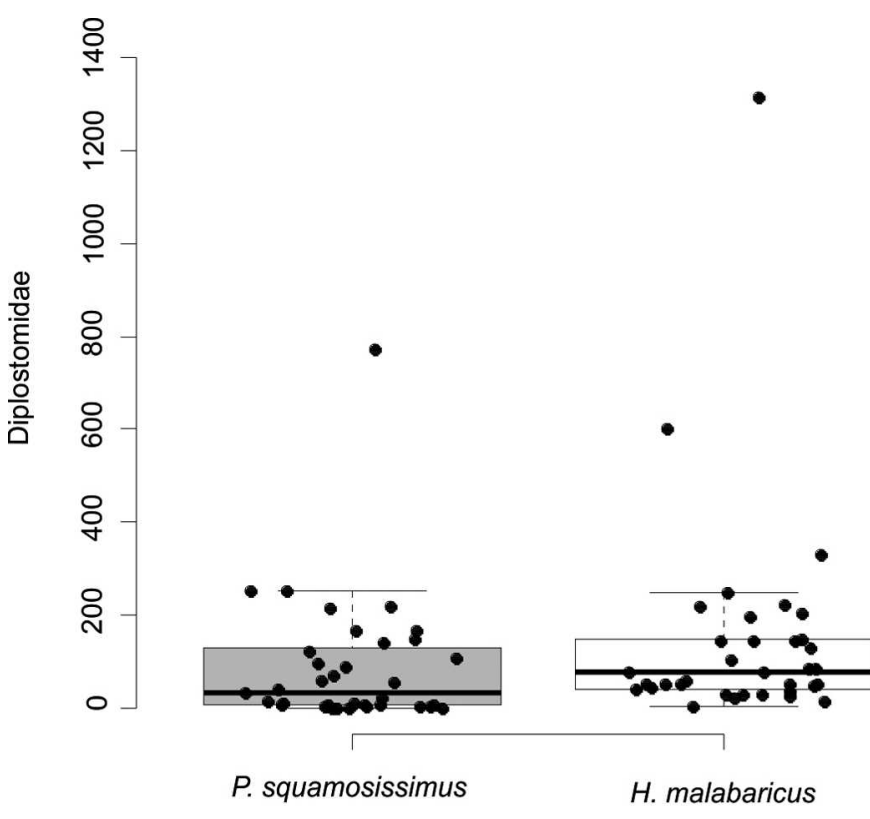

Hosts

Figure 3. Abundance of diplostomid eye flukes in the introduced fish Plagioscion squamosissimus and in the native fish Hoplias malabaricus in the upper Paraná River (box plots represent medians, interquartile ranges, and minimum-maximum ranges without outliers).

probable that $P$. squamosissimus may be acting as a new (and very suitable) host for a local parasite, acting as a reservoir for native parasites from which infections flow back to native hosts. This process is known as spillback (Kelly et al., 2009). However, in the case of Austrodiplostomum sp., spillback could only be assessed with the use of genetic/molecular tools for species differentiation. Similarly, cysts of cestodes (Proteocephalidea) could not be identified to lower taxonomic levels either, so we cannot affirm that they all belong to the same parasite species.

According to our results, $P$. squamosissimus harbors a specific parasite fauna in each environment, since only 2 parasites were found in all the rivers. This demonstrates that, in the case of $P$. squamosissimus, the parasite fauna is more related to the local parasite community than to parasites associated with the original distribution of the fish.

Our study showed that the endoparasite richness of $P$. squamosissimus did not differ between native and invaded environments, but that the composition of species was partially different among localities. These minor differences may suggest the possibility that the fish is "making new enemies" in the invaded environment, but without replicate localities, these remain tentative suggestions requiring further evidence. Host condition was significantly correlated with parasite abundance only in the native environment, possibly reflecting low pathogenicity in the novel parasite-host relationships in invaded areas. In addition, $P$. squamosissimus exhibited lower levels of abundance of eye flukes compared to the native $H$. malabaricus, suggesting that the invader may gain some advantage if competition is occurring.

\section{ACKNOWLEDGMENTS}

We thank E. E. Marques for field assistance. Funding for this research was provided by the National Council for Scientific and Technological Development (CNPq) (Process 471138/2007-0). A. C. F. Lacerda was 
supported by Ph.D. and "Programa de Doutorando com Estágio no Exterior" (PDEE Process 2298/10-4) scholarships from the Coordination for the Improvement of Higher Education Personnel (CAPES). R. M. Takemoto, M. Tavares-Dias, and G. C. Pavanelli were supported by Productivity Grants from the National Council for Scientific and Technological Development.

\section{LITERATURE CITED}

Agostinho, A. A., L. C. Gomes, And F. M. Pelicice. 2007. Ecologia e manejo de recursos pesqueiros em reservatórios do Brasil. Eduem, Maringá, Paraná, Brazil, 501 p.

— , F. M. Pelicice, And H. F. Júlio JR. 2005. Introdução de espécies em águas continentais brasileiras: Uma síntese. In Espécies invasoras em águas doces_-Estudos e caso e propostas de manejo, O. Rocha, E. L. G. Espíndola, N. Fenerich-Verani, R. J. Verani, and A. C. Rietzler (eds.). Editora Federal de São Carlos, São Carlos, Brazil, p. 13-24.

Almeida, S. C. 1998. Ecologia de parasitas de Hoplias malabaricus do Rio Paraná, região de Porto Rico, PR. M.S. Thesis. Universidade Estadual de Maringá, Maringá, Paraná, Brazil, 50 p.

Alvarenga, F. M. S. 2008. Estudo taxonômico e ecológico de endoparasitos do dourado-facão Raphiodon vulpinus Spix \& Agassiz, 1829, na planície de inundação do alto rio Paraná. Monograph. Universidade Estadual de Maringá, Maringá, Paraná, Brazil, 37 p.

Bush, A. O., K. D. Lafferty, J. L. Lotz, and A. W. Shostak. 1997. Parasitology meets ecology on its own terms: Margolis et al. revisited. Journal of Parasitology 83: 575-583.

Eiras, J. C., R. M. Takemoto, and G. C. Pavanelli. 2002. Métodos de estudio y técnicas laboratoriales en parasitología de peces. Editorial Acribia, Zaragoza, Spain, 133 p.

Kelly, D. W., R. A. Paterson, C. R. Townsend, R. Poulin, and D. M. Tompkins. 2009. Parasite spillback: A neglected concept in invasion ecology? Ecology 90: 2047-2056.

Kohn, A., M. B. Fernandes, and M. F. D. Baptista-Farias. 1995. Metacercariae of Diplostomum (Austrodiplostomum) compactum (Trematoda, Diplostomidae) in the eyes of Plagioscion squamosissimus (Teleostei, Scianidae) from the reservoir of the hydroelectric power station of Itaipu, Brazil. Memórias do Instituto Oswaldo Cruz 90: $341-344$.

Le Cren, E. D. 1951. The length-weight relationship and seasonal cycle in gonad weight and condition of perch Perca fluviatilis. Journal of Animal Ecology 20: 201-219.

Locke, S. A., J. D. Mclaughlin, S. Dayanandan, and D. J. Marcogliese. 2010. Diversity and specificity in Diplostomum spp. metacercariae in freshwater fishes revealed by cytochrome c oxidase I and internal transcribed spacer sequences. International Journal for Parasitology 40: 333-343.

Luz-Agostinho, K. D. G., A. A. Agostinho, L. C. Gomes, and H. F. Júlio JR. 2008. Influence of flood pulses on diet composition and trophic relationships among piscivorous fish in the upper Paraná River floodplain. Hydrobiologia 607: 187-198.

Machado, P. M., R. M. Takemoto, and G. C. Pavanelli. 2005. Diplostomum (Austrodiplostomum) compactum (Lutz, 1928) (Platyhelminthes, Digenea) metacercariae in fish from the floodplain of the upper Paraná River, Brazil. Parasitology Research 97: 436-444.

Mack, R. M., D. Simberloff, W. M. Londsdale, H. Evans, M. Clout, AND F. A. BAzZAZ. 2000. Biotic invasions: Causes, epidemiology, global consequences, and control. Ecological Applications 10: 689-710.
Martins, M. L., R. Y. Fujimoto, A. A. Nascimento, and F. R. Moraes. 1999. Ocorrência de Diplostomum sp Nordmann, 1832 (Digenea Diplostomatidae) em Plagioscion squamosissimus Heckel, 1840, proveniente do Reservatório de Volta Grande, MG, Brasil. Acta Scientiarum Biological Sciences 21: 263-266.

—, A. Mello, C. Paiva, And R. Y. Fujimoto. 2001. Prevalência, sazonalidade e intensidade de infecção por Diplostomum (Austrodiplostomum) compactum Lutz, 1928 (Digenea, Diplostomidae), em peixes do reservatório de Volta Grande, Estado de Minas Gerais, Brasil. Acta Scientiarum Biological Sciences 24: 469-474.

Moravec, F. 1998. Nematodes of freshwater fishes of the Neotropical region. Academia, Prague, Czech Republic, 464 p.

Niewiadomska, K. 2005. Family Diplostomidae Poirier, 1886. In Keys to the Trematoda, Vol. 1, D. I. Gibson, A. Jones, and R. A. Bray (eds.). CAB International, London, U.K., p. 167-196.

Nomura, H., 1984 in Carnélos, R. G., and E. Benedito-Cecilio. 2002. Reproductive strategies of Plagioscion squamosissimus Heckel, 1840 (Osteichthyes Scianidae) in the Itaipu Reservoir, Brazil. Brazilian Archives of Biology and Technology 45: 317-324.

R Development Core Team. 2010. R: A language and environment for statistical computing. R Foundation for Statistical Computing, Vienna, Austria. Available at: http://www.R-project.org. Accessed.

RaHel, F. J. 2002. Homogenization of freshwater faunas. Annual Review of Ecology and Systematics 33: 291-315.

Roche, D. G., B. Leung, E. F. Mendoza, and M. E. Torchin. 2010. Higher parasite richness, abundance and impact in native versus introduced cichlid fishes. International Journal for Parasitology 40: $1525-1530$.

Seppälä, O., A. Karvonen, and E. T. Valtonen. 2007. Phenotypic variation in infectivity of Diplostomum spathaceum cercariae within a population. Journal of Parasitology 93: 1244-1246.

SimberlofF, D. 2003. Confronting introduced species: A form of xenophobia? Biological Invasions 5: 179-192.

Souza, A. T. S. 1998. Estudo do parasitismo de Plagioscion squamosissimus (Heckel, 1840) (Perciformes, Scianidae) por Diplostomum (Austrodiplostomum) compactum (Lutz, 1928) (Trematoda, Digenea) no rio Tibagi, PR. Ph.D. Dissertation. Universidade Federal de São Carlos, São Carlos, São Paulo, Brazil, 125 p.

Takemoto, R. M., G. C. Pavanelli, M. A. P. Lizama, A. C. F. Lacerda, F. H. Yamada, S. T. M. Moreira, T. L. Ceschini, and S. Bellay. 2009. Diversity of parasites of fish from the Upper Paraná River floodplain, Brazil. Brazilian Journal of Biology 69: 691-705.

Tavares, L. E. R., C. D. R. SaAd, P. B. Cepeda, and J. L. Luque. 2007. Larvae of Terranova sp. (Nematoda: Anisakidae) parasitic in Plagioscion squamosissimus (Perciformes: Scianidae) from Araguaia River, State of Tocantins, Brazil. Brazilian Journal of Veterinary Parasitology 115: 110-115.

Yamada, F. H., L. H. A. Moreira, T. L. Ceschini, R. M. Takemoto, and G. C. Pavanelli. 2008. Novas ocorrências de metacercária de Austrodiplostomum compactum (Lutz, 1928) (Platyhelminthes: Digenea) parasito de olhos de peixes da bacia do Rio Paraná. Brazilian Journal of Veterinary Parasitology 17: 163-166.

Zica, E. O. P., K. R. Santos, I. P. Ramos, A. S. Zanatta, E. D. Carvalho, AND R. J. Silva. 2009. First case of an infection of the metacercariae of Austrodiplostomum compactum (Lutz, 1928) (Digenea, Diplostomidae) in Hypostomus regani (Ihering, 1905) (Siluriformes: Loricariidae). PanAmerican Journal of Aquatic Sciences 4: 35-38. 